\title{
Anthony D. Smith and the role of art, architecture and music in the growth of modern nations: a comparative study of national parliaments and classical music in Britain and Denmark
}

Article

Accepted Version

Brincker, B. and Leoussi, A. S. (2018) Anthony D. Smith and the role of art, architecture and music in the growth of modern nations: a comparative study of national parliaments and classical music in Britain and Denmark. Nations and Nationalism, 24 (2). pp. 312-326. ISSN 1469-8129 doi: https://doi.org/10.1111/nana.12409 Available at https://centaur.reading.ac.uk/80531/

It is advisable to refer to the publisher's version if you intend to cite from the work. See Guidance on citing.

To link to this article DOI: http://dx.doi.org/10.1111/nana.12409

Publisher: Wiley-Blackwell

All outputs in CentAUR are protected by Intellectual Property Rights law, including copyright law. Copyright and IPR is retained by the creators or other copyright holders. Terms and conditions for use of this material are defined in the End User Agreement. 


\section{www.reading.ac.uk/centaur}

\section{CentAUR}

Central Archive at the University of Reading

Reading's research outputs online 


\title{
Anthony D. Smith and the role of art, architecture and music in the growth of modern nations: a comparative study of National Parliaments and National music in Britain and
}

\section{Denmark}

\author{
By Benedikte Brincker and Athena S. Leoussi
}

\author{
Athena S. Leoussi
}

Athena Leoussi (MPhil, Courtauld Institute of Art; PhD, LSE) is Associate Professor in European History and Director of European Studies in the Department of Modern Languages and European Studies, University of Reading, UK. She is a founder of The Association for the Study of Ethnicity and Nationalism, based at LSE, and the journal, Nations and Nationalism. She has published extensively on the role of the visual arts in nation-building and the influence of the classical Greek cult of the body in re-defining modern European national identities. She was one of the organisers of the British Museum's exhibition, 'Defining Beauty' (2015). Her publications include, Nationalism and Classicism (1998), the Encyclopaedia of Nationalism (Transaction, 2001), Nationalism and Ethnosymbolism (edited with Steven Grosby, 2006), and Famous Battles and How They Shaped the Modern World (2 vols., forthcoming, edited with Beatrice Heuser).

Key words: Nation, National Identity, Agency, Art, Architecture, Parliament, Composer, Music.

\section{Introduction}

In his two books, The Nation made Real (2013) and The Nation and Classical Music (2016), coauthored with Matthew Riley, as well as in other writings, Smith showed how artists, architects, musical composers and other cultural agents in Europe became champions of the idea of the nation from the late eighteenth century onwards and tried, through their works, to convert and draw the wider public 'into the conceptual and emotional world of nationalism' (Smith 2013: 2, 9). This conversion would, in turn, lead to action: the mobilization of communities, who came to think of themselves as 'nations', for the practical realization of the ideals of national 'autonomy, unity and identity'(Ibid: 8). For Smith, '[T]his is where the arts came to play a critical role.' They enabled the 
wider public to 'see the nation' and 'hear its call' (Ibid: 9). This they did by depicting and evoking to these wider, 'national' communities, the atmosphere of their homeland, its landscapes, its myths, the sound of its folksongs, and its distinctive customs and history. Through the arts, the abstract concept of the nation was 'made to seem vivid, palpable and tangible', possessing a 'character, history and destiny' (Ibid: 9). The arts thus played a critical role in the building of modern national self-consciousness and through it, the modern nation-state.

In his writings, Smith set out to show the emergence of a new type of art and architecture - national art and architecture. He also showed the national orientation of much of modern music. Smith's writings on the arts testify to his profoundly interdisciplinary approach to the study of nations and nationalism. These writings are both historical-descriptive and theoretical, providing a richness of conceptual tools for comparison and generalization, such as his division of 'national art' into didactic, evocative and commemorative (Ibid: 2).

This essay takes its inspiration from Smith's work and offers a brief comparative analysis of national parliaments and composers in Britain and Denmark. It examines how ideas of the nation became 'real' in those key public institutions of the two countries, their national parliaments, and through the works of the composers, Ralph Vaughan Williams and Carl Nielsen. Our aim is also to advance cross-national study of national art, architecture and music (Brincker and Brincker, 2004; Brincker, 2014; Leoussi 2004, 2009) and thereby address the critique raised by, among others, Rogers Brubaker, that studies of nations and nationalism have a tendency of generating noncumulative knowledge that does not move beyond the insights that one acquires from single case studies (Brubaker 2004). In response to Brubaker, and building on Smith, we show, first, the role of the arts in official and popular definitions of national identity in Britain and Denmark; and second, the existence of formal patterns in European national art, architecture and music as the idea of the nation spread across Europe. 
How did British and Danish parliamentary buildings make the British and Danish nations 'real'?

The importance of national parliamentary buildings for the study of the nation and especially the study of national identity in Europe lies in the fact that these buildings have been and remain central sites of national expression and representation. Their emergence, as a new type of monumental public building in the old and new national capitals of Europe, beginning, at least symbolically, with the conversion, from 1791 onwards, of the Palais Bourbon in Paris into a national assembly hall, visibly established the centrality of national and individual freedom through representative democracy, in the culture of modern European societies

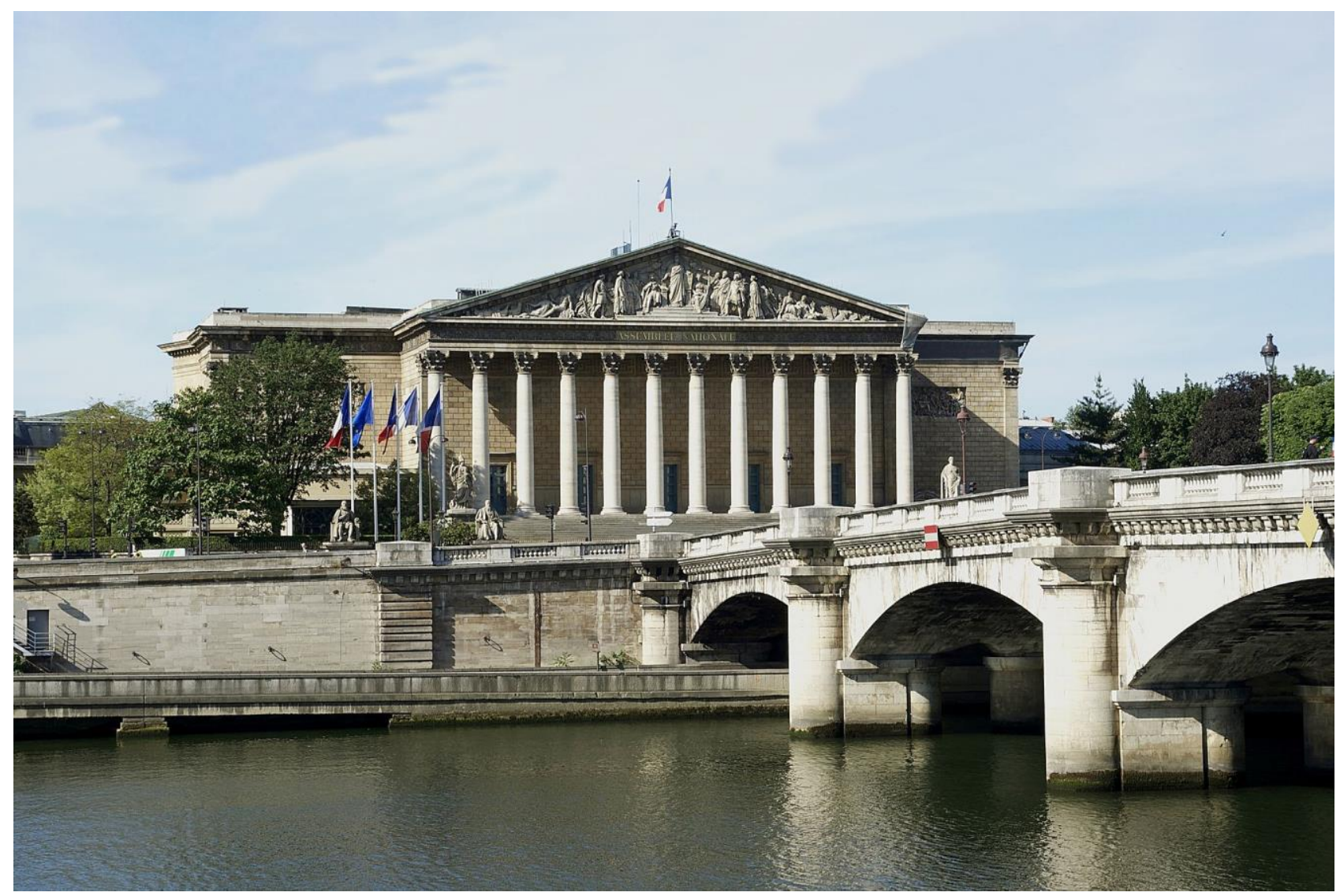


Fig. 1. French Parliament (Palais Bourbon), in Paris (the new façade with the typically classical twelve columns was completed in 1810) https://commons.wikimedia.org/wiki/Category:Palais_Bourbon

As houses of national assemblies, parliamentary buildings have tended to project, and be shaped, in their architectural style and decoration, by the ideal of national self-government and conceptions of the history and culture of the nation or nations which are represented in these assemblies. They are thus symbols and vehicles of visions of the sovereign nation, expressed and made 'real' through visual representation (Smith 2013).

As a political and national institution, the modern parliament was largely inspired from classical Athens. This classicism also inspired the architectural style and often the interior design and decoration (the paintings, sculptures, tapestries etc.) of the buildings that housed national assemblies, not only in Europe but also the USA (the US Capitol, designed by William Thornton in 1792 but subsequently modified) and the rest of the world, from the late eighteenth century onwards. 


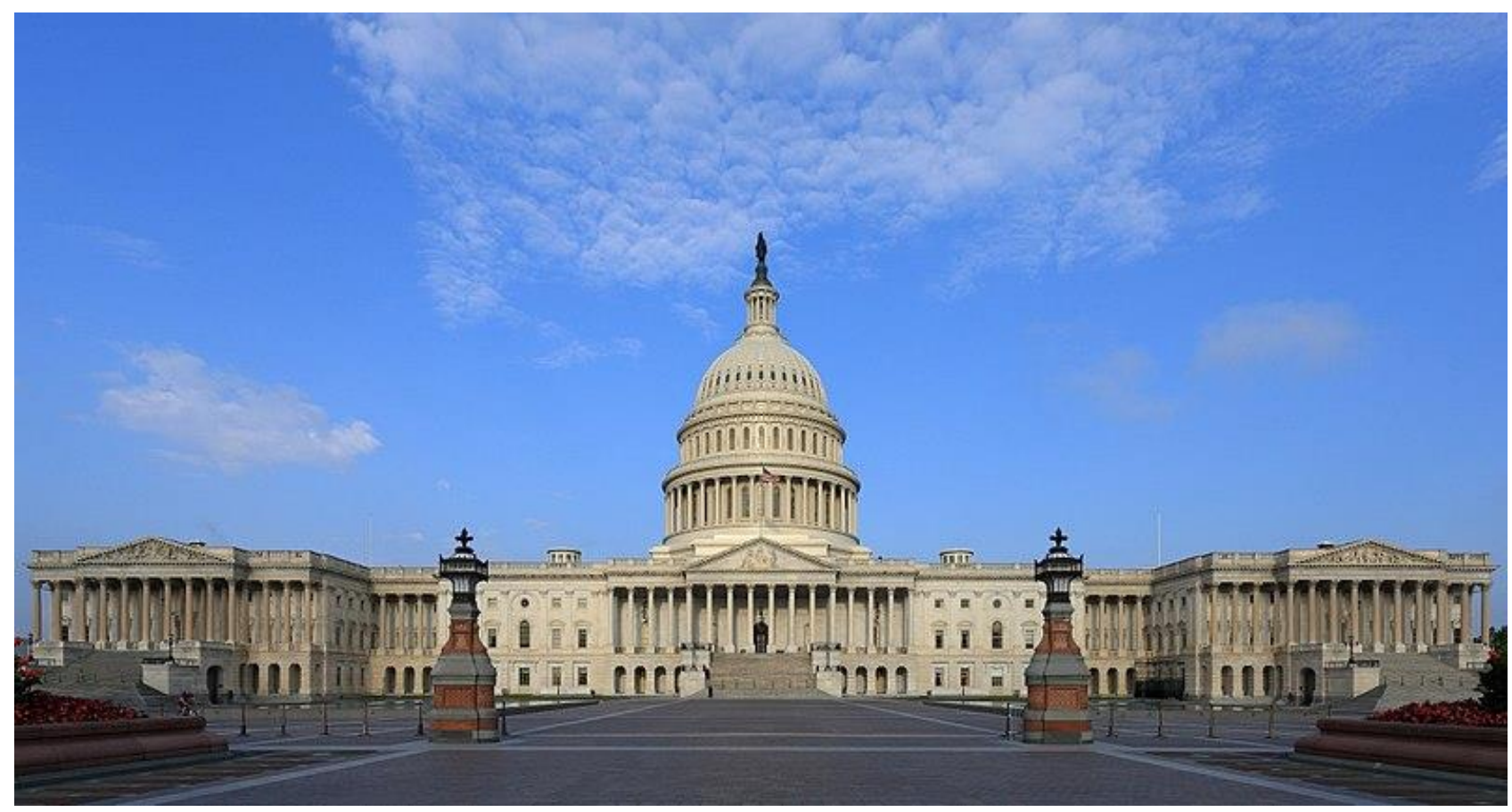

Fig. 2. US Capitol, Washington, DC (first designed in 1792 and subsequently modified many times),

\section{https://commons.wikimedia.org/wiki/File:US Capitol east side.JPG}

This ensured that the Greek, classical model of modern democracy and nationality was clearly acknowledged and made visible and enduring through the new architectural and artistic style that emerged in the late eighteenth century and became known as 'neo-classicism'. Indeed, Anthony D. Smith has emphasised 'the pivotal role of "neo-classicism" in the formation of modern nations' alongside that of biblical traditions (Smith 2016: 20). The conversion of the former Palais Bourbon in Paris to house the French Assemblee Nationale expressed the Greek origins of modern democracy and also the Greek origin of a particular type of national community that the French Revolutionary patriots sought to create and empower - the nation as a communtity of citizens (Kohn 2005; Schnapper 2017). Greek references abound not only in the style of the new façade, a neo-classical portico, designed by the architect Bernard Poyet and completed in 1810, but also in the design of the debating hall, 'l'hémicycle', which was inspired by the ancient Greek theatre: 
'l’Antiquité grecque, qui inventa la démocratie, nous a aussi légué le théâtre' (Assemblée Nationale 2017). Similarly classical have been the Austrian (Imperial) parliamentary building (1873) and the German, the Reichstag (completed in 1894) both built in the nineteenth century.

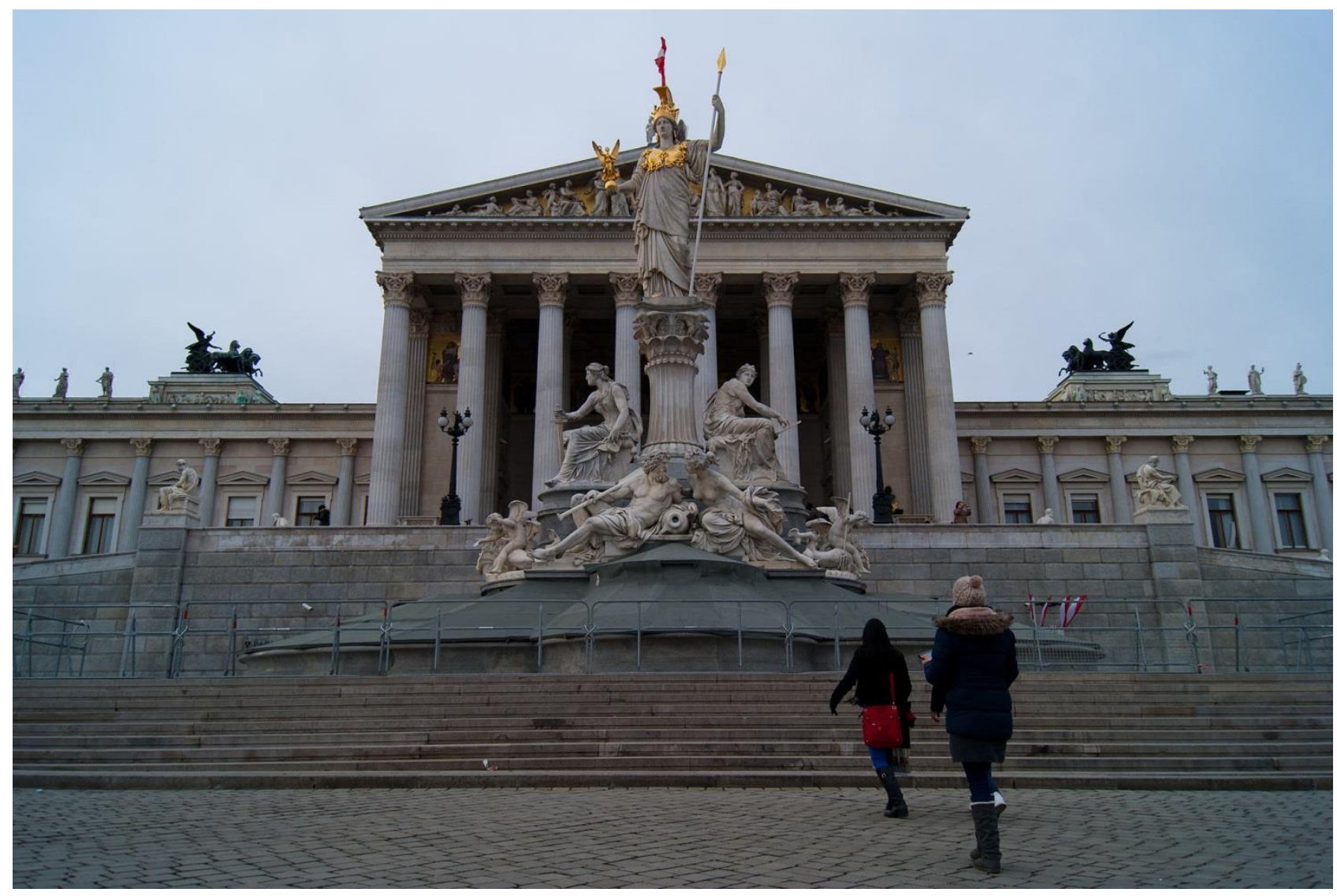

Fig. 3. Austrian Parliament in Vienna (1873), https://commons.wikimedia.org/wiki/Category:Pallas Athena statue, Vienna\#/media/File :Atine statue and Austrian Parliament (8441082485).jpg 


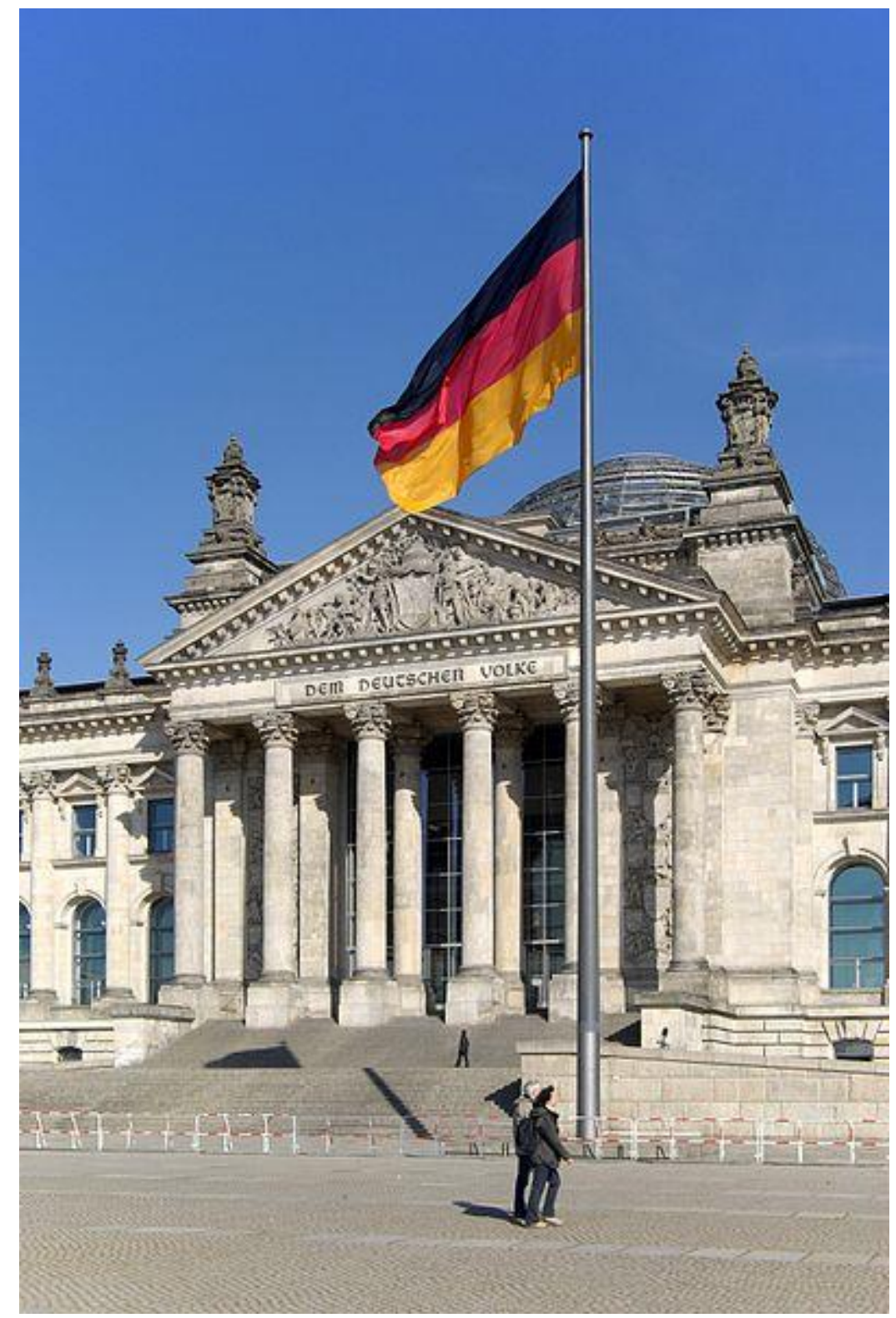

Fig. 4. German Parliament (the Reichstag, 1894),

https://commons.wikimedia.org/wiki/File:Berlin_Reichstag_BW_1.jpg

However, the classical style and classical iconography have not been the only style or iconography of European national parliaments. As far as architectural styles are concerned, there are three main types of architectural style that have shaped parliamentary buildings in Europe: the classical style; national historical styles, such as the Gothic style that was chosen for the re-built British Houses of Parliament (1837-67); and modernist styles that have transcended or amalgamated both classical 
and local-national tradition, and have provided new forms of architectural expression (e.g. the Slovak parliamentary building or the 'avant-garde', albeit unrealised designs of 1947 by Jože Plečnik for the Slovene parliament in Ljubljana that features a conical tower. It can be seen on the back of Slovenia's ten-cent euro coin. Significantly, Plečnik's design is also known as the 'Cathedral of Freedom' and 'Slovene Acropolis'. These labels, on the one hand express the importance of the Slovene parliament as a shrine of the modern religion of freedom, as grand as the old cathedrals; and, on the other, declare the connection of modern Slovene parliamentary democracy with ancient Athenian democracy.

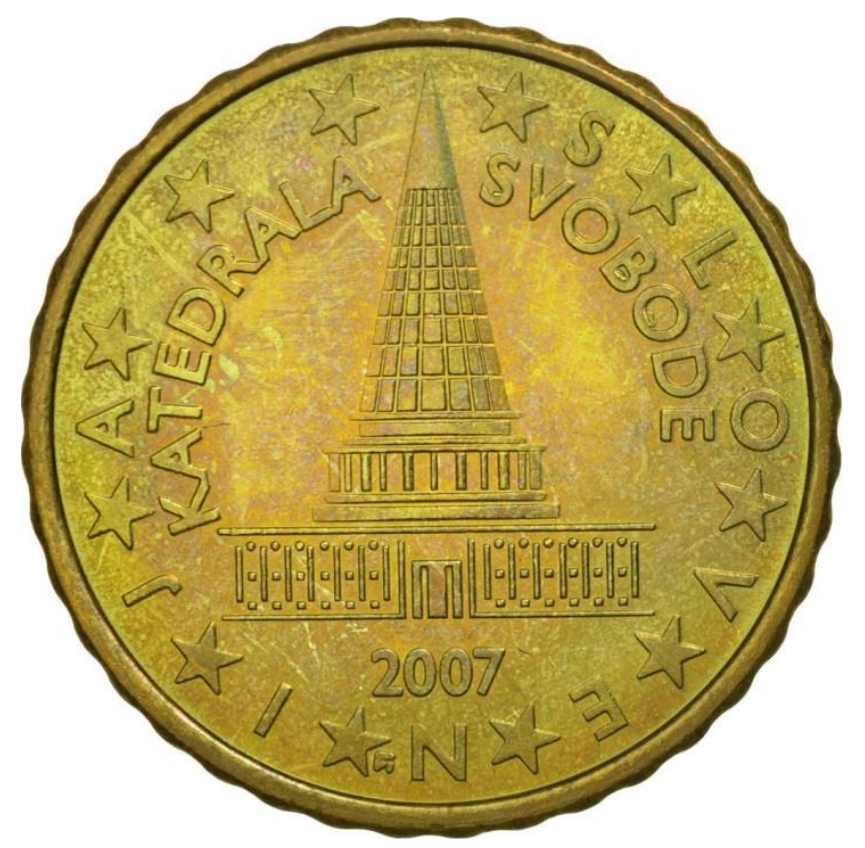

Fig. 5. Jože Plečnik's unrealised plans for the Slovenian Parliament, https://www.ebay.co.uk/itm/463485-Slovenia-10-Euro-Cent-2007-AU-55-58-Brass-KM71/201943989916?hash=item2f04ccbe9c:g:x28AAOSwBt5ZMKT-

See also: https://ec.europa.eu/info/about-european-commission/euro/euro-coins-andnotes/euro-coins/national-sides-euro-coins/slovenia en, Accessed 6 February 2018.

These styles show the tension between civic-universalist and ethnic-particularist conceptions of the national self (Kohn 2005); they also show an attempt to combine different elements of these 
conceptions and the invention of new visual vocabularies for the ideas of nation and democracy that the notion of the sovereign nation typically implied.

Let us now look at the British and Danish national parliamentary buildings. Here, we present original material taken primarily from official parliamentary websites. The current Palace of Westminster in London replaced an earlier, medieval structure which was burned down in 1834. The new structure was built between 1835 and 1860, on designs by Charles Barry and Augustus Pugin.

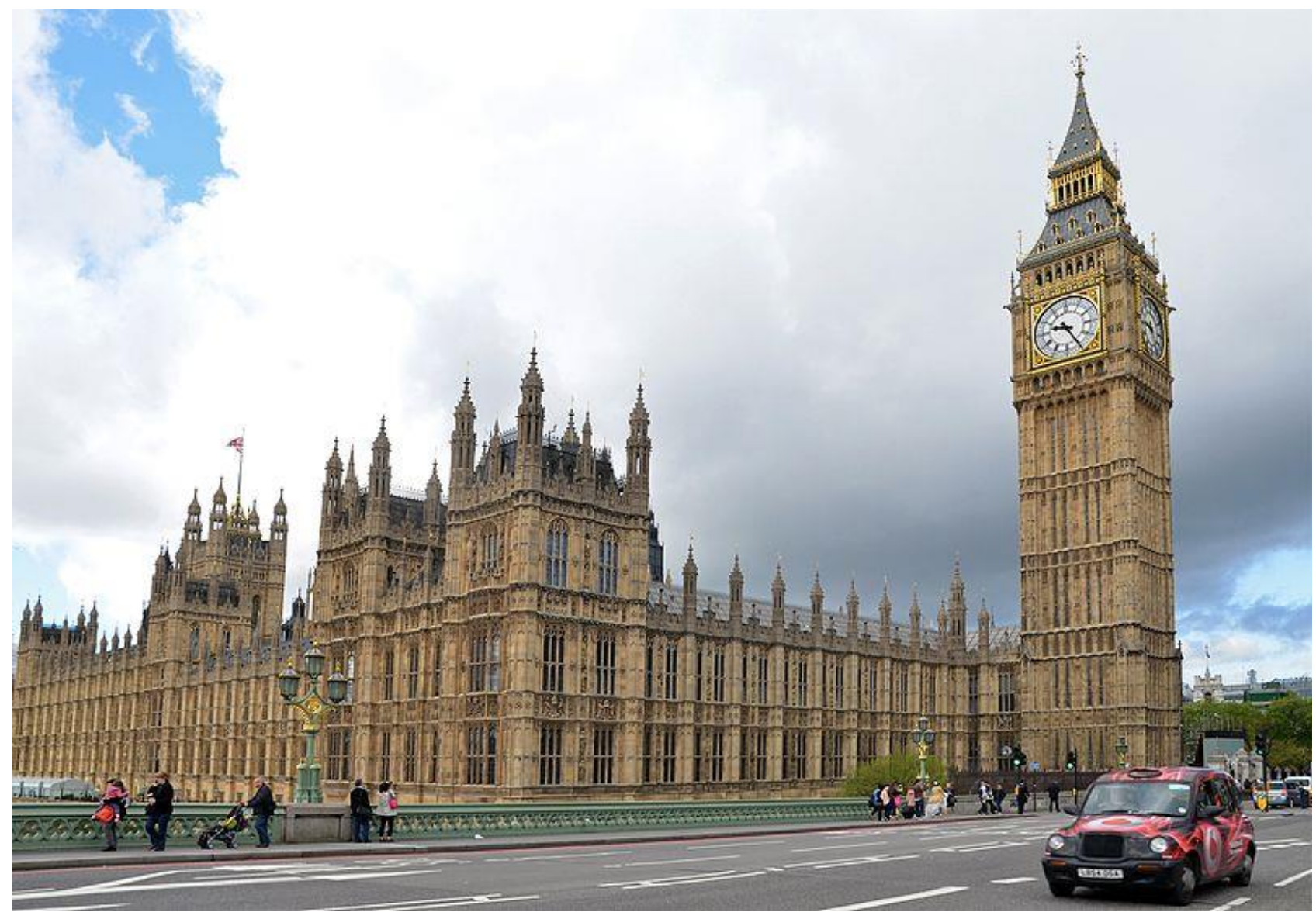

Fig. 6. Westminster Palace (British Houses of Parliament, 1835-60), https://commons.wikimedia.org/wiki/File:Houses of Parliament - panoramio (4).jpg 
The Palace of Westminster was built in an English style, the Gothic Revival style that was developed in England to avoid the revolutionary and republican associations of the classical revival in the USA and France. Yet even the English Parliament has classical features, for example in its proportions and symmetry. As the Gothicist Pugin famously remarked: 'All Grecian, sir; Tudor details on a classic body' (UK Parliament 2017).

The new Palace of Westminster was custom-built for Parliamentary use. As the official website of the Palace of Westminster notes,

'The design and layout of the building were thus carefully designed to serve the needs and workings of Parliament. In particular, Barry [its chief architect] placed the location of the Sovereign's throne, the Lords Chamber and the Commons Chamber in a straight line, thus linking the three elements of Parliament in continuous form.'(Ibid., neo-gothic-vision)

In 1841, a Commission was set up under Prince Albert to encourage contemporary artists to submit designs to decorate the building. The designs were required to be on national subjects, and especially on national history. This meant, in the first instance, English history, 'covering the whole field of English history'. Some three hundred statues were also commissioned to decorate the main facades of the building, representing saints and sovereigns from the Norman conquest to Queen Victoria. Consequently, the Palace of Westminster was designed not just to be a working building for the Lords and Commons but also to project an account not only of English, but also British history. This affirmed the diversity and long history of the British people as well as its monarchs. Other decorations affirm the multi-national character of Britain such as Charles Barry's Lobby, where the patron saints of the four constituent nations of the United Kingdom, England, Wales, Scotland and (now Northern) Ireland, appear on large mosaic panels, installed between 1870 and the early 1920s. 
Paintings by William Dyce illustrate the British chivalric virtues of hospitality, generosity, mercy, religion and courtesy, as represented through scenes from the legend of King Arthur and his court. While the walls of the Royal Gallery are decorated by two enormous paintings by Daniel Maclise 'recording significant moments from the Napoleonic wars. One of them depicts 'The Meeting of Wellington and Blucher' and portrays the meeting of the Duke of Wellington and the Prussian Field Marshall Blucher at the La Belle Alliance inn before defeating Napoleon at the Battle of Waterloo in $1815^{\prime}$. We thus also find images of national resistance, although not always successful, to foreign rule.

The current building of the Danish Parliament, the Folketing, is located in the Christiansborg Palace on the Castle Islet, "Slotsholmen", a small island in Copenhagen harbour, in the heart of the capital (Danish Parliament, 2017).

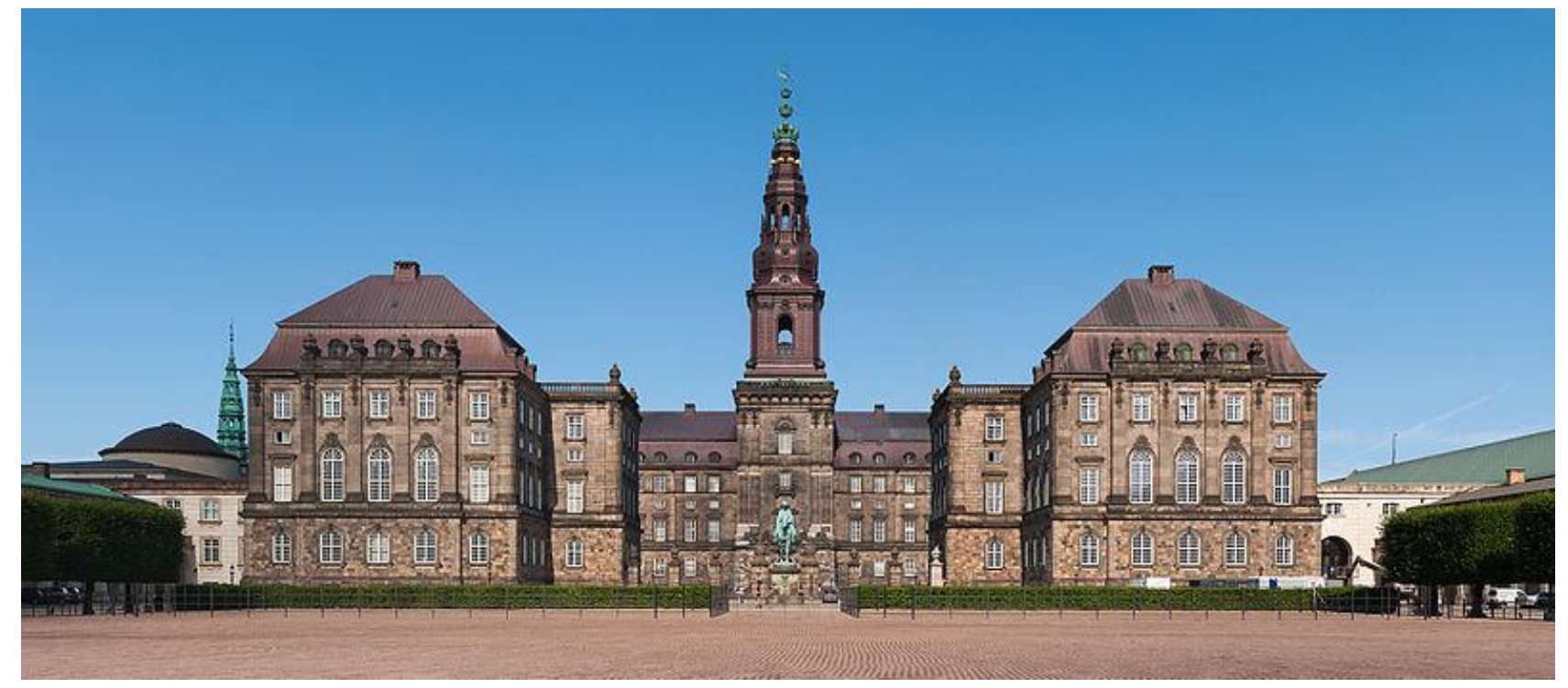

Fig. 7. The third Christiansborg Slot (Christiansborg Palace) seat of the Folketing, the Danish Parliament (1907-28), https://commons.wikimedia.org/wiki/File:Christiansborg Slot Copenhagen 2014 01.jpg

Both the British and Danish parliamentary buildings show in their structure and decorations the intertwining of monarchical with national-democratic ideas, both states being constitutional 
monarchies (the Danish from 1849, onwards). But unlike the modern British parliament, the building which housed the first Danish parliament in modern times was originally a royal palace, known as the second Christiansborg Palace. It was built after the first Christiansborg Palace (built between 1731 and 1745), a Baroque building, burned down in 1794. The second Christiansborg Palace was built between 1803 and 1833 in the neoclassical style, by the great Danish neo-classical architect, Christian Frederik Hansen (1756 - 1845). Hansen took part in the huge work of reconstruction after the great fire of 1795 .

Hansen's neo-classical style for the second Christiansborg Palace had no democratic connotations. It was inspired by the French Empire variety of neo-classicism. Indeed, the Museum that was dedicated to the great neo-classical and liberal Danish sculptor, Bertel Thorvaldsen (1770-1844), Thorvaldsens Museum, the first museum building in Denmark, which was opened in September 1848, would stand in close proximity to but in defiance of Christiansborg Palace, at that time, the symbol of absolute monarchy (Schindler 2017;Thorvaldsens Museum 2017 However, the year 1848, the year during which democratic and national revolutions swept across much of Europe, also had an impact on Danish politics. It transformed, in 1849, the government of Denmark into a constitutional monarchy and, with it, the function of Christiansborg Palace. With the transition to a constitutional monarchy, King Frederik VII decided to hand over part of the palace to the Parliament. In this context, the neoclassical style became congruent with its typically democratic associations. The second Christiansborg Palace was also burned down in 1884. It was not until 1907, that King Frederik VIII laid the foundation stone for the third and present-day Christiansborg Palace, which was completed in 1928 and inaugurated by King Christian X. It was built in the neobaroque style, with different coloured marbles on its facade, representing the different regions of Denmark. As the official website of the Danish Parliament states, 'The ponderous, robust 
expression was intended to emphasise the role of the building as the country's political heart.' It brings together both the royal and the democratic institutions of Denmark:

...Christiansborg is not only a workplace for politicians and parliamentary employees. The Royal Reception Rooms, which are located on the first floor in the north wing, are at the disposal of the Royal Family, and the Queen performs many of her official duties there. The Prime Minister's Office is located above the Royal Reception Rooms, and the Supreme Court, the highest court in Denmark, next to them. Thus, the country's most important and powerful institutions are all at Christiansborg (Danish Parliament 2017)

In its function as a house of representatives of the Danish nation, the current Christiansborg Palace bears national characteristics. These are combined with references to the monarchy and its long history. References to the national, folk culture, the culture of the people, seem to dominate the imagery of the nation as compared with British parliamentary decoration. This is evident in a series of tapestries with motifs from Danish folk ballads, designed by Joakim Skovgaard (1856 - 1933). A large ceiling painting by Kræsten Iversen in the Throne Room depicts Dannebrog, meaning, 'the flag of the Danes', which, according to legend fell from the sky in Estonia in a battle in 1219. This theme gives deep historical depth to both the history of the monarchy and the Danish nation. Indeed, more recently, in 2000, a series of 17 tapestries with historical themes was installed in the Great Hall, affirming 1000 years of Danish history. They were a gift to the Queen by the Danish business community.

Important political documents are kept in the Lobby, such as the first democratic Constitutional Act of 1849 , 'where the King handed over power to the people'. These trace the long historical 
evolution of sovereign power in Denmark, and include the 1915 Act, which 'gave the majority of the Danish population their democratic rights' (Ibid., 1915).

\section{How did composers in Britain and Denmark make the British and Danish nations 'real'?}

When approaching music in Europe in la longue durée (Armstrong 1982), classical music seems to dominate it as an international phenomenon that is closely associated with the life at the courts in Europe. Traditionally, musicology has been very reluctant to engage with processes of nation building and has been inclined to consider classical music a phenomenon that is 'classical', in the sense of universal and beyond national differences. The Palestrina style was not considered an Italian style. Instead, it was considered a classical vocal polyphony. By the same token, the Bach style was not considered German or even central European but the culmination of the linear counterpoint (Brincker and Brincker, 2004: 580). However, this reading of the history of classical music is challenged in the second part of the twentieth century when the American musicologist Richard Taruskin embarked upon the endeavor to uncover national elements of the very same music that European musicology had traditionally considered universal and beyond national differences (Taruskin 1996; 1997).

The belief that classical music captures a universal musical expression is dominant among both musicologists and composers in the late nineteenth and early twentieth century Europe. However, especially in the first decades of the twentieth century, composers and especially those in the peripheral nations in Europe seek to discover and / or construct a national musical style that could complement, possibly even substitute, the traditional repertoire of the concert halls and musical theatres. This tendency is strongly pronounced in both Britain and Denmark where Ralph Vaughan Williams (1872-1958) and Carl Nielsen (1865-1931) - the latter in collaboration with Thomas Laub 
(1852-1927) - collect and disseminate folk songs and hymns from the past of Britain, especially England and Denmark respectively (Laub and Nielsen, 1915; Williams, 1912, 1906). They do so against the backdrop of the fact that neither Britain nor Denmark had pronounced national musical traditions. In the case of Britain, up until the second part of the nineteenth century its musical life was dominated by performances of foreign composers by foreign musicians (Brincker, 2003b). In the case of Denmark, its nineteenth-century musical life was in a similar way strongly influenced by continental European composers and musicians, most notably from the German duchies Slesvig and Holstein that were part of the Danish conglomerate state (Brincker 2003a).

The absence of national musical traditions that could match those of mainland Europe inspired Vaughan Williams and Carl Nielsen to discover alleged authentic national musical expressions in Britain and Denmark respectively. In this way, they would also offer an alternative to the Romantic and similarly international musical expression deriving from central Europe.

In the first part of the twentieth century both Nielsen and Williams published collections of folk songs. In so doing, they reflected upon the place of these collections and thus their own efforts in contributing cultural material that fed into the building and consolidation of the British and Danish nation states. In the case of Williams, he was very explicit that his endeavor to collect folk songs was part of his hope to provide a foundation of English folk songs that could serve as a basis for a British national musical expression. Here neither the Welsh choral tradition nor the Scottish bag pipes were considered suitable. However, he was quick to point out that his endeavor to collect English songs and hymns was not a nationalistic endeavor in the political sense of the word.

Instead, he argued it stemmed from and resonated with the community that he was part of. In 1934, Williams writes: 'What a composer has to do is to find out the real message he has to convey to the community and say it directly and without equivocation... The composer must not shut himself up 
and think about art; he must live with his fellows and make art his expression of the whole life of the community. If we seek art we shall not find it' (Williams 1987 [first edition 1934]: 9-10).

Similarly, Nielsen was confronted with allegations of being a nationalist (Thaning 2005-2006; Marstal, 2005-2006). He reflected upon these allegations that were made regarding the collection of folk songs that he carried out in close collaboration with Thomas Laub. Laub and Nielsen were very explicit about approaching this task in the context of their desire to do away with the excessive complexity that they believed characterized compositions of the Romantic era (Nielsen, 1954; Leerssen, 2006, 2014; Lajosi, 2014). Thus, to Nielsen and Laub the collection of folk songs was part of an aspiration to go back to a simple and pure expression typically captured in a simple song characterised by emotions and sensitivity. In doing this, Nielsen and Laub were strongly influenced by Die Zweite Berliner Liederschule (The Second Berlin School) and the late eighteenth-century composer, John Abraham Peter Schultz. In an interview on his $60^{\text {th }}$ birthday in 1925, Nielsen was offered the chance to reflect upon his alleged nationalism when he was asked about his view of 'national music'. Nielsen replied: 'Nothing destroys music more than nationalism does... and it is impossible to deliver national music on request....If music becomes national it is because those that take it to their hearts make it national' (Nielsen 1925; printed in Fellow, 1999, p. 354, authors' translation from Danish into English).

There is a striking resemblance in the way that Williams and Nielsen deal with and confront the critique that their endeavors to collect English and Danish songs respectively were a nationalist endeavor. Both Williams and Nielsen explicitly emphasise the significance of folk culture in their oeuvre. Furthermore, they stress that in the event that their compositions are perceived to be particularly national - making the nation 'real' - it is because they are received and interpreted as such by the audience and thus the community that the composer is part of and with whom his works resonate. Hence, while Williams and Nielsen underline that they are part of, and embedded in a 
wider cultural community, they stress that they cannot be held accountable for the ways in which their work is received and interpreted by that community. Hence, it is never quite clear who assigns national significance to music and its creators (Brincker and Brincker, 2004).

While there are obvious similarities between Nielsen and Williams, there are also differences. Whereas William's way into the English songs and hymns was that of a collector's, Nielsen picked up the Danish folk songs as a child and son of a peasant on the Danish island Funen. His journey from a peasant's son to the most distinguished composer Denmark has ever had has been emphasized both by Nielsen himself and by musicologists. This journey has become an important part of Nielsen's position as the Danish national composer par excellence (Nielsen 1927; Jensen 1991; Grimley in Murphy and White (eds.), 2001). This constitutes a break with the otherwise compelling parallels between Williams and Nielsen.

As we have seen both Williams and Nielsen were highly critical of the abstract notion of national art - more precisely of national music. Both preferred to address this notion in the context of audience receptions and interpretations rather than composers' intentions. Yet, at least in the case of Nielsen, it appears that even if he did not perceive himself to be a nationalist, he knew how to tap into the national sentiments that defined Denmark at the time and benefit from them both personally and professionally (Marstall 2005-2006). A pronounced example of this is his opera Masquerade (1906) which builds upon the comedy by Ludvig Holberg (1684-1754). Holberg was the most popular writer of the eighteenth century and is often referred to as the 'Molière of the North'. His mass audience looked upon his work as emancipatory (Reynolds 2010: 260). In both Holberg's comedy and Nielsen's opera the masquerade is at one level a distraction from the hardship of everyday life. However, at another level it is closely associated with freedom within a restrictive and old-fashioned society. It conveys the message that only when being behind masks that hide age, social status, etc. are we equal and free. Nielsen's engagement with the play's central dramatic 
conflict between tradition and modern notions of freedom is evident both in the dramatic theme and in the music of the opera. The latter is clearly expressed in the contrast between art music and folklike song styles that Nielsen employed in the opera most notably in Act I, where Jeronimus, the father of the main character Leander and prime representative of the older generation, sings the song 'Fordum var der Fred på Gaden' (The good old days) (Reynolds 2010: 267). Up until that point in the opera the drama has progressed at a rapid speed. This speedy dénouement is supported by Nielsen's 'shifting diatonicism' that adds musical momentum to the speedy development of the

drama. However, this comes to a hault when Jeronimus takes his place at the center stage and sings 'Fordum var der Fred på Gaden' without preamble in the purest C major (ibid). He sings about longing for the old days, when there were order and hierarchy and does so in a musical style characterised by emotion and sensitivity. The folk-song like style of the song is out of place in the context of the opera and supports Nielsen's endeavor to reveal the gulf between tradition and modernity - the central dramatic theme of the opera (Ibid). 'Fordum var der Fred på gaden' became without comparison the most popular number in the entire opera and secured it a place in the popular arena. People were able to sing along to the simple song of Jeronimus and read their own longings into it. Indeed, audiences took it to their hearts as a national song.

\section{Conclusion}

What we may conclude from the brief examination of British and Danish parliamentary buildings and the works of the composers Ralph Vaughan Williams and Carl Nielsen, is the importance of the cultural dimension of modern European nation-building. As Smith has shown, the study of the arts, and especially their comparative study, offers unique insights into a) the visual and musical ways with which the abstract idea of the 'nation' can be made visible, audible and thus realizable; and b) 
the pattern of these imaginative 'realisations' across Europe - their differences and similarities. Furthermore, and building on Smith's work, we tried to show, a) that the study of the arts reveals the distinctively artistic aspects and expressions of national identity. These include the creation of powerful visual and musical symbols of this identity and the development of national visual and musical styles and forms; and b) that the close study of the arts shows the complexity of attributing the term 'national' to behavior, including artistic behavior and its products - works of art, architecture and music.

\section{References}

Web-sources:

Assemblée Nationale. http://www.assemblee-nationale.fr/histoire. Accessed 22 December 2017. Thorvaldsens Museum. http://www.thorvaldsensmuseum.dk/en/museum/the-museumbuilding.Accessed 22 December 2017.

Danish Parliament: http://www.thedanishparliament.dk/Visit_the_Danish_Parliament/The_history_of_Christians borg_Palace.aspx, Acccessed 22 December 2017.

Danish Parliament. http://www.thedanishparliament.dk/1915/whathappenedin1915.aspx. Accessed 22 December 2017

UK Parliament. http://www.parliament.uk/about/livingheritage/building/palace/architecture/palacestructure/rebuilding-palace/, Accessed 2 December 2017.

\section{References}

Armstrong John. 1982. Nations before Nationalism. Chapel Hill: The University of North Carolina Press

Brincker, Benedikte. 2014. 'The role of classical music in the construction of nationalism: a crossnational perspective'. Nations and Nationalism, Vol. 20, No. 4, pp. 664-682 
Brincker, Benedikte. 2008. 'The role of classical music in the construction of nationalism: an analysis of Danish consensus nationalism and the reception of Carl Nielsen'. Nations and Nationalism. Vol. 14. No. 4, pp. 684-700

Brincker, Benedikte and Brincker, Jens. 2004. Musical constructions of nationalism: a comparative study of Bartók and Stravinsky'. Nations and Nationalism. Vol. 10, No. 4, pp. 579-599 Brincker, Benedikte. 2003a. "A "Small Great National State": An Analysis of the Cultural and Political Factors that shaped Danish Nationalism 1760-1870'. Journal of Historical Sociology, Vol. 16, No. 4, pp. 407-432

Brincker, Benedikte. 2003b. Cultrual Foundations of the Common Foreign and Security Policy of the European Union. Copenhagen: Copenhagen Political Studies Press Brubaker, Rogers. 2004. Ethnicity without groups. Harvard: Harvard University Press. Fellow, John (ed.) 1999. Carl Nielsen i sin samtid. Vol. 1. Copenhagen: Gyldendal

Jensen, Jørgen I. 1991. Carl Nielsen. Danskeren. Copenhagen: Gyldendal Kohn, Hans. 2005 [1944]. The Idea of Nationalism. A Study in its Origins and Background, with a new introduction by Craig Calhoun, New Brunswick, N.J: Transaction Laub, Thomas and Nielsen, Carl. 1915. En snes danske viser. Copenhagen: Wilhelm Hansen (ed nr 1953)

Leerssen, Joep. 2006. National Thought in Europe: A Cultural History. Amsterdam: Amsterdam University Press

Leerssen, Joep. 2014. 'Romanticism, music, nationalism'. Nations and Nationalism, Vol. 20, No. 4, pp. 606-628

Lajosi, Krisztina. 2014. 'National stereotypes and music. Nations and Nationalism. Vol. 20. No. 4, pp. $628-646$ 
Leoussi, Athena S. 2004.'The ethno-cultural roots of national art', Nations and Nationalism, Vol. 10, Parts 1/2, pp. 141-157.

Leoussi, Athena S. 2009. 'From civic to ethnic classicism: the cult of the Greek body in late nineteenth-century French society and art', International Journal of the Classical Tradition, Institute for the Classical Tradition, Boston University, 16, 3/4: 393-442.

Marstall, Henrik. 2005/2006. 'Carl Nielsen: Vor store (danske) komponist' Dansk Musik Tidsskrift. Vol. 80, No. 3, pp. 88-91

Nielsen, Carl. 1927. Min fynske Barndom. Copenhagen: Martin Forlag

Reynolds, Anne-Marie. 2010. Carl Nielsen's Voice: His Songs in Context. Copenhagen: Museum Tusculanum

Riley, Matthew and Smith, Anthony D. 2016. Nation and Classical Music: From Handel to Copland. Woodbridge: Boydell and Brewer.

Schindler, Tabea. 2017.“The box built in Nordic-Arabian-Egyptian style”: Geographical mobility and cultural translation in Thorvaldsens Museum', in Sara Ayres and Elettra Carbone (eds.), Sculpture and the Nordic Region, London: Routledge: 71-87.

Schnapper, Dominique. 2017 [1994, 1998]. Community of Citizens: On the Modern Idea of Nationality, London: Routledge.

Smith, Anthony D. 2013. The Nation Made Real: Art and National Identity in Western Europe 1600-1850, Oxford: Oxford University Press.

Smith, Anthony D. 2016. 'Classical Ideals and the Formation of Modern Nations in Europe', in Thorsten Fögen and Richard Warren, Graeco-Roman Antiquity and the Idea of Nationalism in the 19th Century, Berlin: De Gruyter: 19-44.

Taruskin, Richard. 1996. Stravinsky and the Russian Traditions: a Bibliography through the Works of Mavra. Berkeley CA: University of California Press 
Taruskin, Richard. 1997. Defining Russia Musically: Hisitorical and Hermeneutical Essays.

Princeton NJ: Princeton University Press

Thaining, Fie. 2005/2006. 'Når kunst og kultur nationaliseres’ Dansk Musik Tidsskrift. Vol. 80. No.

4, pp. $150-154$

White, Harry and Murphy, Michael (eds.). 2001. Musical constructions of nationalism. Cork: Cork

University Press

Williams, Ralph Vaughan. 1934. National Music and other essays. Oxford: Oxford University

Press (Second Edition 1987)

Williams, Ralph Vaughan and Loyd, A. 1912. English Folk Songs. London: Penguin English

Journeys

Williams, Ralph Vaughan. 1906. The English Hymnal. Oxford: Oxford University Press 